\title{
Screening of genetic loci predisposing to herpes simplex virus infection on mouse chromosome 17
}

\author{
Xiu-Ying Chen ${ }^{1}$, Wei-Ju Tang ${ }^{1}$, Xu-Zheng Zuo ${ }^{1}$, Gong Wang ${ }^{1}$, Hao-Xiang Wang ${ }^{1}$, Peng Xie ${ }^{2}$, Wen Huang ${ }^{1}$ \\ ${ }^{1}$ Depatment of Neurology, Xinqiao Hospital, the Third Military Medical University, Chongqing 400037, China. \\ ${ }^{2}$ Depatment of Neurology, the First Affiliated Hospital, Chongqing Medical University, Chongqing 400016, China.
}

Correspondence to: Prof. Wen Huang, Depatment of Neurology, Xinqiao Hospital, the Third Military Medical University, Chongqing 400037, China. E-mail: huang_wen@163.com

How to cite this article: Chen XY, Tang WJ, Zuo XZ, Wang G, Wang HX, Xie P, Huang W. Screening of genetic loci predisposing to herpes simplex virus infection on mouse chromosome 17. Neuroimmunol Neuroinflammation 2016;3:274-82.

Article history:
Received: $24-04-2016$
Accepted: $02-11-2016$
Published: 26-12-2016
Key words:
Herpes simplex virus,
susceptibility to infection,
microsatellite site,
association analysis,
mouse chromosome 17

\section{INTRODUCTION}

As an infection relapse could confer severe consequence in the pathogenicity of herpes simplex virus (HSV) infection, avoiding infection and preventing recurrence after treatment is of great importance. Individual differences involved in the pathogenesis of

\begin{abstract}
Aim: The herpes simplex virus (HSV), one of the most common viruses infecting humans, is featured by a high infection rate and usually causes complex disorders difficult to diagnose and treat. Disease progression is always combined with the specific interaction between organism and environment, but genetic factors play a decisive role in most pathogenic processes. Like most human disorders, individual difference has also been involved in the pathogenesis of HSV infection. The present study aimed to screen the potential gene loci that regulates human predisposition to HSV infection. Methods: With reference to previous studies, inbred mouse lines with significantly distinct predisposition to HSV infection were chosen for gene loci screening. Gene sites on mouse chromosome 17 associated with susceptibility to HSV infection were then identified by correlation analysis and genome-wide scanning technique. Results: Genes affecting the vulnerability of mice to HSV infection were mapped to three regions on the 17th mouse chromosome, D17MIT51.1, D17MIT39.1 and the region between D17MIT180.1 and D17MIT184. Conclusion: The results suggest that the mouse genetic background plays an important role in its susceptibility to HSV-1 infection, which might be regulated by multiple predisposing quantitative trait loci.
\end{abstract}

HSV infection in mice have been long studied. Several reports related to HSV infection susceptibility further pointed to the role of genetic background in the HSV infection process. ${ }^{[1-5]}$ To further analyze the susceptibility to HSV infection in different inbred mouse lines, we scanned the 17th mouse chromosome for gene sites associated with it using the correlation analysis and

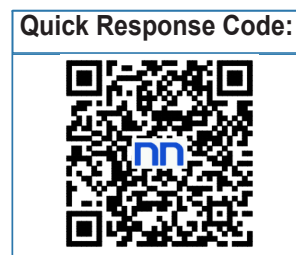


genome-wide scanning technique.

\section{METHODS}

\section{Genomic DNA extraction}

Firstly, 50-100 frozen tissue samples were weighed, grinded into powder in liquid nitrogen using a grinding bowel and pestle, and then immediately mixed with $1 \mathrm{~mL}$ Tripure. Tissue sample powder was then further homogenized 10 times using a homogenizing drill on ice for 20 min until no tissue fluid particles was visible, centrifuged at the speed of $12,000 \mathrm{~g}$ at $4{ }^{\circ} \mathrm{C}$, for $10 \mathrm{~min}$. The homogenate was then kept at room temperature for $5 \mathrm{~min}$ to make sure the nuclear protein was totally separated. Each milliliter homogenate was mixed with $0.3 \mathrm{~mL}$ chloroform and shaken vigorously at $4{ }^{\circ} \mathrm{C}$ for $15 \mathrm{~s}$, kept at room temperature for 2-15 min, then Centrifuged at $12,000 \mathrm{~g}$ at $4{ }^{\circ} \mathrm{C}$, for $15 \mathrm{~min}$. To get high quality DNA, the upper layer of colorless aqueous liquid after centrifugation was removed. Each milliliter homogenate was mixed with $0.2 \mathrm{~mL} 100 \%$ ethanol which was stored at $4{ }^{\circ} \mathrm{C}$, mixed completely by rotating the bottle upside down several times and kept at room temperature for 2-3 min for DNA precipitation. After centrifuging at $2,000 \mathrm{~g}$ for $5 \mathrm{~min}$ at $4{ }^{\circ} \mathrm{C}$, the upper layer liquid was removed with a pipette carefully. Each milliliter sample solution was then mixed with $1 \mathrm{~mL}$ of $0.1 \mathrm{~mol} / \mathrm{L}$ sodium citrate dissolved in $10 \%$ ethanol, kept at room temperature for $30 \mathrm{~min}$ with frequent mixing, and centrifuged at $4{ }^{\circ} \mathrm{C}$ for $5 \mathrm{~min}$ at 2,000 $\mathrm{g}$ again. The upper layer liquid was collected, mixed with $75 \%$ ethanol, and kept at room temperature for 30 min with frequent mixing. Then, after centrifuging at $4{ }^{\circ} \mathrm{C}$ and 2,000 $\mathrm{g}$ for $5 \mathrm{~min}$, the upper layer liquid was removed and the DNA sample was dried in the air or vacuum for 5-10 min. Finally, we dissolved the DNA with $50 \mathrm{uL} \mathrm{TE}$ solution, pipetted out $1 \mathrm{uL}$ sample for color comparison and another $10 \mathrm{uL}$ for electrophoresis, and the residual was stored at $-20{ }^{\circ} \mathrm{C}$ for further analysis. DNA samples were diluted with $90 \mathrm{uL} \mathrm{MQ}$ water and analyzed with ultraviolet spectrophotometer. The OD260 value, OD280 value and OD260/280 value were used for calculating the concentration of DNA.

\section{Primer design and synthesis}

Primer design referenced information from the mouse genome program (detailed information can be viewed on the website of Jackson Laboratory), which was designed by Shanghai Jikang Biotechnology Limited Company [Table 1]. The detailed information about $\mathrm{PCR}$ reaction system and $\mathrm{PCR}$ reaction condition can be seen in Table 2.

\section{Microsatellite loci detection}

First, $1 \mathrm{~mL}$ Hi-Di Formamide was mixed with $50 \mathrm{uL}$
GeneScan -500 LIZ Size Standard, then mixed with $9.5 \mathrm{uL}$ polymerase chain reaction (PCR) product, which was diluted 20 times. Tubes containing the above solution were placed in the PCR instrument for degeneration at $95{ }^{\circ} \mathrm{C}$ for $5 \mathrm{~min}$, kept on ice for more than 5 min. Using an ABI PRISMTM 310 genetic analyzer of the $\mathrm{ABI}$ Company for electrophoresis, the voltage was set to $15 \mathrm{KV}$ and run at $60{ }^{\circ} \mathrm{C}$ for $28 \mathrm{~min}$. The samples were then collected for further analysis.

\section{Electrophoresis data processing}

By using the software Genescan (311) and Genetyper (3.7), we could get the detected fragment size. The equipment was provided by $A B I$ Company; the PCR amplification reagents by Baosheng Bioengineering Limited Company; and the fluorescent primers by Shanghai Jikang Biotechnology Limited Company.

\section{RESULTS}

\section{Scanning 12 microsatellite spots on the 17 th} chromosome of two mouse lines

The differences of 12 microsatellite loci between two inbred mouse lines BALB/C and C57BL/6 were first scanned. Among the loci scanned, seven of them were significantly different: D17MIT245.1, D17MIT46, D17MIT51.1, D17MIT180.1, D17MIT20. 1, D17MIT184 and D17MIT39.1 [Table 3; Figure 1].

Scanning microsatellite loci on the 17th chromosome using three inbred mouse lines To minimize false-positives among the above seven sites obtained using the two inbred mouse lines, we further searched the literature and found that another inbred mouse line, DBA-2, had similar susceptibility to HSV infection as BALB/C mice. Therefore, scanning these three inbred mouse lines for microsatellite loci led to the exclusion of two of the above seven loci, D17MIT245.1 and D17MIT46. Our updated scanning results showed that D17MIT51.1, D17MIT39.1 and the genomic region between D17MIT180.1 and D17MIT184 were mouse microsatellite regions affecting susceptibility to HSV infection [Table 4; Figure 2].

Bioinformatic analysis of genes in the HSV infection susceptibility regions on chromosome 17

For identifying potential genes involved in the susceptibility of mice to HSV infection, we used bioinformatics to analyze the genes localized in these regions. Based on the above results, bioinformatic analysis found approximately 140 genes in the positive sites D17MIT51.1, D17MIT39.1 and the region between D17MIT180.1 and D17MIT184 [Tables 5-7]. Among those genes, there were about 33 human 
Table 1: Primer sequences for scanning microsatellite loci on the 17th chromosome of mouse genome

\begin{tabular}{|c|c|c|c|}
\hline Loci name & & Primer sequence & Genetic distance (cM) \\
\hline \multirow[t]{2}{*}{ D17MIT245.1 } & Forward & FAM-TGTGCTCTGGCTAGGGAGTT & 3 \\
\hline & Reverse & CACATTCATATGTACACACACATGC & \\
\hline \multirow[t]{2}{*}{ D17MIT143.2 } & Forward & FAM-CTTACAAGCATCCTGTGGAACTC & 5 \\
\hline & Reverse & GAGGACCAACAGTCAAACATAGC & \\
\hline \multirow[t]{2}{*}{ D17MIT46 } & Forward & FAM-TCCACСССАСТАССТGАCTC & 11.7 \\
\hline & Reverse & СССTTCTGATGACCACAGGT & \\
\hline \multirow[t]{2}{*}{ D17MIT146.1 } & Forward & FAM-CTGTCAGCAGAACGTTCCTTAGT & 17.1 \\
\hline & Reverse & CCAACTCAAGCСTTACATAGTGG & \\
\hline \multirow[t]{2}{*}{ D17MIT51.1 } & Forward & FAM-TCTGCCCTGTAACAGGAGCT & 22.9 \\
\hline & Reverse & CTTCTGGAATCAGAGGATCCC & \\
\hline \multirow[t]{2}{*}{ D17MIT10.1 } & Forward & FAM-TGCACTTGCATAAGGAAAAC & 24.5 \\
\hline & Reverse & GACTTTGGGGCCTACTTATG & \\
\hline \multirow[t]{2}{*}{ D17MIT180.1 } & Forward & FAM-AGACACTGTCTAAAAACACAAGATGG & 29.4 \\
\hline & Reverse & TTGTGTTCATATGCATGTGTGC & \\
\hline \multirow[t]{2}{*}{ D17MIT20.1 } & Forward & FAM-AGAACAGGACACCGGACATC & 34.3 \\
\hline & Reverse & TCATAAGTAGGCACACCAATGC & \\
\hline \multirow[t]{2}{*}{ D17MIT184 } & Forward & FAM-TGCACTACCCAAACATGCAT & 38.5 \\
\hline & Reverse & ACTTCTGACAGGAAGCATCCA & \\
\hline \multirow[t]{2}{*}{ D17MIT93.1 } & Forward & FAM-TGTCCTTCGAGTGTTTGTGTG & 44.5 \\
\hline & Reverse & TCCCCGGTGAATGAGTTATC & \\
\hline \multirow[t]{2}{*}{ D17MIT39.1 } & Forward & FAM-CCTCTGAGGAGTAACCAAGCC & 45.3 \\
\hline & Reverse & CACAGAGTTCTACCTCCAACCC & \\
\hline \multirow[t]{2}{*}{ D17MIT122.1 } & Forward & FAM-TCTCTTCACTGCAATGGAACA & 51.9 \\
\hline & Reverse & GAACCTATAGGCTCTTGAATAGATGG & \\
\hline
\end{tabular}

homologous genes that showed some of the following characteristics: (1) containing many quantitative trait loci, such as epididymal fat pad weight quantitative trait loci (QTL) 3, subcutaneous fat pad weight QTL 4, spleen weight QTL 9, etc.; (2) containing some genes related to the important physiological functions of the body such as Mut methylmalonyl-Coenzyme A mutase; (3) containing genes related to the developmental and physiological function such as early growth adjusted QTL 2, early growth QTL 5, etc.; (4) containing genes associated with some diseases such as the

Table 2: PCR reaction system and PCR reaction condition

\begin{tabular}{ll}
\hline PCR reaction system (total volume: $\mathbf{1 0} \mathrm{uL})$ & \\
\hline Non-enzyme water & $5.4 \mu \mathrm{L}$ \\
$10 \times \mathrm{PCR}$ buffer & $1.0 \mathrm{uL}$ \\
$\mathrm{Mg}^{2+}(25 \mathrm{mmol} / \mathrm{L})$ & $0.5 \mathrm{uL}$ \\
$\mathrm{dNTP}($ each $2.5 \mathrm{mmol} / \mathrm{L})$ & $1.0 \mu \mathrm{L}$ \\
$\mathrm{P} 1(5 \mathrm{pM})$ & $0.5 \mathrm{uL}$ \\
$\mathrm{P} 2(5 \mathrm{pM})$ & $0.5 \mathrm{uL}$ \\
Template DNA $(30-50 \mathrm{ng} / \mathrm{uL})$ & $1.0 \mathrm{uL}$ \\
Ex-Taq enzyme $(5 \mathrm{U} / \mathrm{LL})$ & $0.1 \mu \mathrm{L}$ \\
PCR reaction condition & \\
$95{ }^{\circ} \mathrm{C}$ & $5 \mathrm{~min}$ \\
$94{ }^{\circ} \mathrm{C}$ & $30 \mathrm{~s}$ \\
Time & $30 \mathrm{~s}$ \\
$72{ }^{\circ} \mathrm{C}$ & $30 \mathrm{~s}$ \\
Repeat the 2 nd to 4 th steps for totally 38 cycles & \\
$72{ }^{\circ} \mathrm{C}$ & $10 \mathrm{~min}$ \\
Store at $4{ }^{\circ} \mathrm{C}$ &
\end{tabular}

PCR: polymerase chain reaction
Down syndrome critical region gene 1-like 1, MSM lymphoma resistance 1 , etc.; (5) containing mouse tissue associated antigen $\mathrm{H}-2$.

\section{DISCUSSION}

It has been widely observed that different species or even individuals of the same species show differences in response to infection, but the explanation for this phenomenon is still rather controversial. There have

Table 3: Microsatellite loci scanning using BALB/C and C57BL/6 inbred mice

\begin{tabular}{lcc|}
\hline Microsatellite loci & $\begin{array}{c}\text { BALB/C } \\
\text { susceptible }\end{array}$ & $\begin{array}{c}\text { C57BL/6 } \\
\text { tolerant }\end{array}$ \\
\hline D17MIT245.1 & $\mathbf{1 9 4}$ & $\mathbf{2 0 2}$ \\
D17MIT143.2 & 112 & 112 \\
D17MIT46 & $\mathbf{2 1 8}$ & $\mathbf{2 3 6}$ \\
D17MIT146.1 & 166 & 166 \\
D17MIT51.1 & 152 & 154 \\
D17MIT10.1 & 155 & 155 \\
D17MIT180.1 & 139 & 137 \\
D17MIT20.1 & 163 & 175 \\
D17MIT184 & 126 & 128 \\
D17MIT93.1 & 155 & 155 \\
D17MIT39.1 & 86 & 104 \\
D17MIT122.1 & 141 & 141 \\
\hline
\end{tabular}

Microsatellite loci with difference were marked in bold 
Table 4: Microsatellite loci scanning using BALB/C, DBA-2 and C57BL/6 inbred mice

\begin{tabular}{lccc}
\hline \multirow{2}{*}{$\begin{array}{l}\text { Microsatellite } \\
\text { loci }\end{array}$} & \multicolumn{2}{c}{ Susceptible } & Tolerant \\
\cline { 2 - 4 } & BALB/C & DBA-2 & C57BL/6 \\
\hline D17MIT245.1 & 194 & 200 & 202 \\
D17MIT143.2 & 112 & 112 & 112 \\
D17MIT46 & 218 & 208 & 236 \\
D17MIT146.1 & 166 & 166 & 166 \\
D17MIT51.1 & 152 & 152 & 154 \\
D17MIT10.1 & 155 & 149 & 155 \\
D17MIT180.1 & 139 & 139 & 137 \\
D17MIT20.1 & 163 & 163 & 175 \\
D17MIT184 & 126 & 126 & 128 \\
D17MIT93.1 & 155 & 169 & 155 \\
D17MIT39.1 & 86 & 86 & 104 \\
D17MIT122.1 & 141 & 123 & 141 \\
\hline
\end{tabular}

Microsatellite loci with difference were marked in bold

been reports suggesting that the genetic background might play an important role..$^{[1,6-8]}$ The causative factors for different responses to infection, the possible ways of intervention, the revolutionary changes of infection prevention, and the control that resulted from those changes have aroused great interest among the scientific community. In this study, we analyzed the genetic background that contributes to the HSV infection susceptibility.
The Herpes virus genus (Herpesviridae) is among the enveloped, linear, double-stranded DNA viruses that widely exist in nature. Approximately $100 \mathrm{HSV}$ species have already been identified or partially identified. Among them, two HSV species, SV-1 and HSV-2, that share $50 \%$ homology, have been closely associated with humans. According to statistics provided by the WHO, approximately $70 \%$ of the total population worldwide carries HSV antibodies and more than onethird suffers from recurrent HSV infection. Along with its high prevalence rate, a variety of human diseases are closely related with HSV infection, including human herpes labialis, herpes conjunctivitis, 20 herpes zoster encephalitis and other diseases causing great harm to human health. HSV encephalitis is the most common, sporadic, viral encephalitis, accounting for $10-20 \%$ of acute, viral, encephalitis and $60-80 \%$ of natural mortality. Understanding the complex and specific characteristics of HSV infection-related diseases has been a scientifically and socially pressing need that has led to overcoming the recent difficulties in diagnosis and treatment.

Table 5: Bioinformatics of genes in microsatellite loci D17MIT51.1 region

\begin{tabular}{|c|c|c|c|}
\hline No. & Mouse genome & $\begin{array}{l}\text { Corresponding } \\
\text { human genes }\end{array}$ & Functions \\
\hline $\begin{array}{c}1 \\
2 \\
3 \\
4 \\
5 \\
6 \\
7 \\
8 \\
9 \\
10 \\
11 \\
12 \\
13 \\
14 \\
15 \\
16 \\
17 \\
18 \\
17 \\
18 \\
19 \\
20 \\
21 \\
22 \\
23 \\
24 \\
25 \\
26 \\
27 \\
28 \\
29 \\
30 \\
31 \\
32 \\
33 \\
34 \\
35 \\
36 \\
37 \\
38 \\
39\end{array}$ & 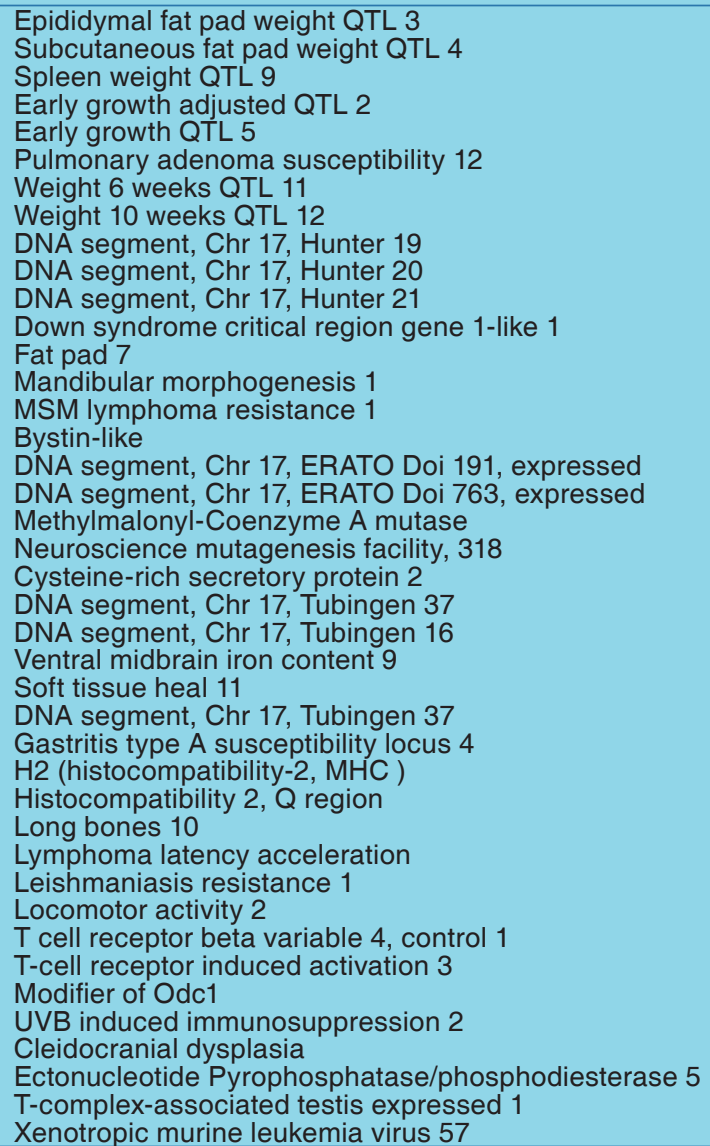 & $\begin{array}{l}\text { DSCR1L1 } \\
\text { BYSL } \\
\text { MUT } \\
\text { CRISP2 }\end{array}$ & $\begin{array}{c}\text { QTL } \\
\text { QTL } \\
\text { QTL } \\
\text { Complex/cluster/region } \\
\text { Complex/cluster/region } \\
\text { QTL } \\
\text { QTL } \\
\text { QTL } \\
\text { QTL } \\
\text { QTL } \\
\text { QTL } \\
\text { QTL } \\
\text { QTL } \\
\text { Complex/cluster/region detail }\end{array}$ \\
\hline
\end{tabular}

QTL: quantitative trait loci 
Table 6: Bioinformatics of genes in microsatellite loci D17MIT39.1 region on the 17 mouse chromosome

\begin{tabular}{|c|c|c|c|}
\hline No. & Mouse genome & $\begin{array}{l}\text { Corresponding } \\
\text { human genes }\end{array}$ & Functions \\
\hline 1 & Laminin receptor 9 & & \\
\hline 2 & Proteoglycan induced arthritis 20 & & QTL detail \\
\hline 3 & Ribosomal protein L19, related sequence 8 & & pseudogene \\
\hline 4 & T-cell integration locus & & \\
\hline 5 & Xanthine dehydrogenase & $X D H$ & xanthine dehydrogenase \\
\hline 6 & Sine oculis-related homeobox 2 homolog (Drosophila) & $S I X 2$ & \\
\hline 7 & Sine oculis-related homeobox 3 homolog (Drosophila) & SIX3 & \\
\hline 8 & MutS homolog 2 (E. coli) & MSH2 & $\begin{array}{l}\text { DNA mismatch repair protein, eukaryotic } \\
\text { MSH2 type }\end{array}$ \\
\hline 9 & Carcass protein in high growth mice 3 & & QTL \\
\hline 10 & DNA segment, Chr 17, XREFdb 57 & & \\
\hline
\end{tabular}

QTL: quantitative trait loci

Table 7: Bioinformatics of genes in microsatellite loci from D17MIT180.1 to D17MIT184 region

\begin{tabular}{|c|c|c|c|}
\hline No. & Mouse genome & $\begin{array}{l}\text { Corresponding } \\
\text { human genes }\end{array}$ & Functions \\
\hline 1 & High mobility group nucleosomal binding domain 1, related sequence 8 & & \\
\hline 2 & Cyclin D3 & CCND3 & \\
\hline$\overline{3}$ & Ecotropic viral integration site 14 & & \\
\hline 4 & High mobility group nucleosomal binding domain 2 . related sequence 4 & & \\
\hline 5 & DNA segment, Chr 17, Roswell Park 11, expressed & & \\
\hline 6 & Transplantation-specific integration cluster 1 & & \\
\hline 7 & Body weight 2 & & \\
\hline $\begin{array}{l}8 \\
9\end{array}$ & $\begin{array}{l}\text { DNA segment, Chr 17, CEPH } 9 \\
\text { DNA segment. Chr } 17 \text {, Le Roy } 1\end{array}$ & & \\
\hline $\begin{array}{c}9 \\
10\end{array}$ & $\begin{array}{l}\text { DNA segment, Chr 17, Le Roy } 1 \\
\text { DNA segment, Chr 17, Tubingen } 40\end{array}$ & & \\
\hline 11 & P300/CBP-associated factor & PCAF & \\
\hline 12 & Progastricsin (pepsinogen C) & $P G C$ & \\
\hline 13 & Thymus specific insertion locus & & \\
\hline 14 & Meprin 1 alpha ;MGI:96963 & MEP1A & \\
\hline 15 & DNA segment, Chr 17 , Seldin 7 & & \\
\hline 16 & Macrophage migration inhibitory factor, pseudogene 8 & & Pseudogene \\
\hline 17 & Cerebellar cAMP 8 & & QTL \\
\hline 18 & DNA segment, Chr 17, John C. Schimenti 39 & & \\
\hline 19 & DNA segment, Chr 17, National Cardiovascular Center, Shionogi 7 & & \\
\hline 20 & DNA segment, Chr 17, National Cardiovascular Center, Shionogi 34 & & \\
\hline 21 & DNA segment, Chr 17, XREFdb 556 & & \\
\hline 22 & abdominal fat weight 3 & & QTL \\
\hline 23 & DNA segment, Chr 17 , Abbott 3 & & \\
\hline 24 & DNA segment, Chr 17, Birkenmeier 8 & & \\
\hline 25 & DNA segment, Chr 17 , Tubingen 20 & & \\
\hline 26 & Heligmosomoides polygyrus nematode resistance 7 & & QTL \\
\hline 27 & Heligmosomoides polygyrus nematode resistance 7 & & QTL \\
\hline 28 & Obesity and body weight QTL 4 & & QTL \\
\hline 29 & RAB5A, member RAS oncogene family & RAB5A & \\
\hline 30 & Skin tumor susceptibility $10^{\circ}$ & & QTL \\
\hline 31 & DNA segment, Chr 17, Brigham Young University 2 & & \\
\hline 32 & High density lipoprotein (HDL) level 4 & & QTL \\
\hline 33 & Vav 1 oncogene & VAV1 & \\
\hline 34 & Nrtn ;neurturin; & NRTN & \\
\hline 35 & Creatine kinase, brain, related sequence 2 & & \\
\hline 36 & Epstein-Barr virus induced gene 3 & $E B / 3$ & \\
\hline 37 & DNA segment, Chr 17 , Hunter 24 & & \\
\hline 38 & Ephrin A5 & EFNA5 & \\
\hline 39 & RAS-like, family 2 , locus 3 & & \\
\hline 40 & Protein tyrosine phosphatase, receptor type, S & PTPRS & \\
\hline 41 & Abdominal fat percentage 1 & & QTL \\
\hline 42 & P. chabaudi malaria resistance QTL 7 & & \\
\hline 43 & Caseinolytic peptidase, ATP-dependent, proteolytic subunit homolog (E. coli) & CLPP & \\
\hline 44 & Plasmacytoma susceptibility 5 & & \\
\hline 45 & Ribosomal protein L32, related sequence 7 & & Pseudogene \\
\hline 46 & Sulfotransferase family, cytosolic, $1 \mathrm{C}$, member 1 & & \\
\hline 47 & DNA segment, Chr 17 , Tubingen 23 & & \\
\hline 48 & Complement component 3 & C3 & \\
\hline 49 & CD86 expression in activated macrophages & & QTL \\
\hline 50 & DNA segment, Chr 17 , Hunter 15 & & \\
\hline 51 & DNA segment, Chr 17, University of California at Los Angeles 2 & & \\
\hline 52 & EGF-like module containing, mucin-like, hormone receptor-like sequence 1 & EMR1 & \\
\hline 53 & EGF-like module containing, mucin-like, hormone receptor-like sequence 4 & EMR4 & \\
\hline 54 & Modifier of obesity 4 & & QTL \\
\hline 55 & Fer (fms/fps related) protein kinase, testis specific 1 & & \\
\hline
\end{tabular}


tubulin, beta 4 TUBB4

DNA segment, Chr 17, ERATO Doi 599, expressed

DNA segment, Chr 17, Hunter 16

SH3-domain GRB2-like 1

SH3GL1

Thin fur

QTL

Early somite stage arrest $15 a$

HDL QTL 29

$\mathrm{KH}$-type splicing regulatory protein

Regulatory factor X, 2 (influences HLA class II expression)

Skeletal muscle weight 5

DNA segment, Chr 17, Wayne State University 104, expressed

DNA segment, Chr 17, XREFdb 173

Immune response 5

Feminization 1 homolog a (C. elegans)

DNA segment, Chr 17, Indiana University Medical 1

DNA segment, Chr 17, John C. Schimenti 20

DNA segment, Chr 17, XREFdb 181

Laminin, alpha 1

RalA binding protein 1

Twisted gastrulation homolog 1 (Drosophila)

Protein tyrosine phosphatase, receptor type, $\mathrm{M}$

Age related hearing loss 3

Stathmin 1, related sequence 2

Abdominal fat weight QTL 7

DNA segment, Chr 17, Birkenmeier 9

DNA segment, Chr 17, Brigham and Women's Genetics 1496 expressed

QTL: quantitative trait loci

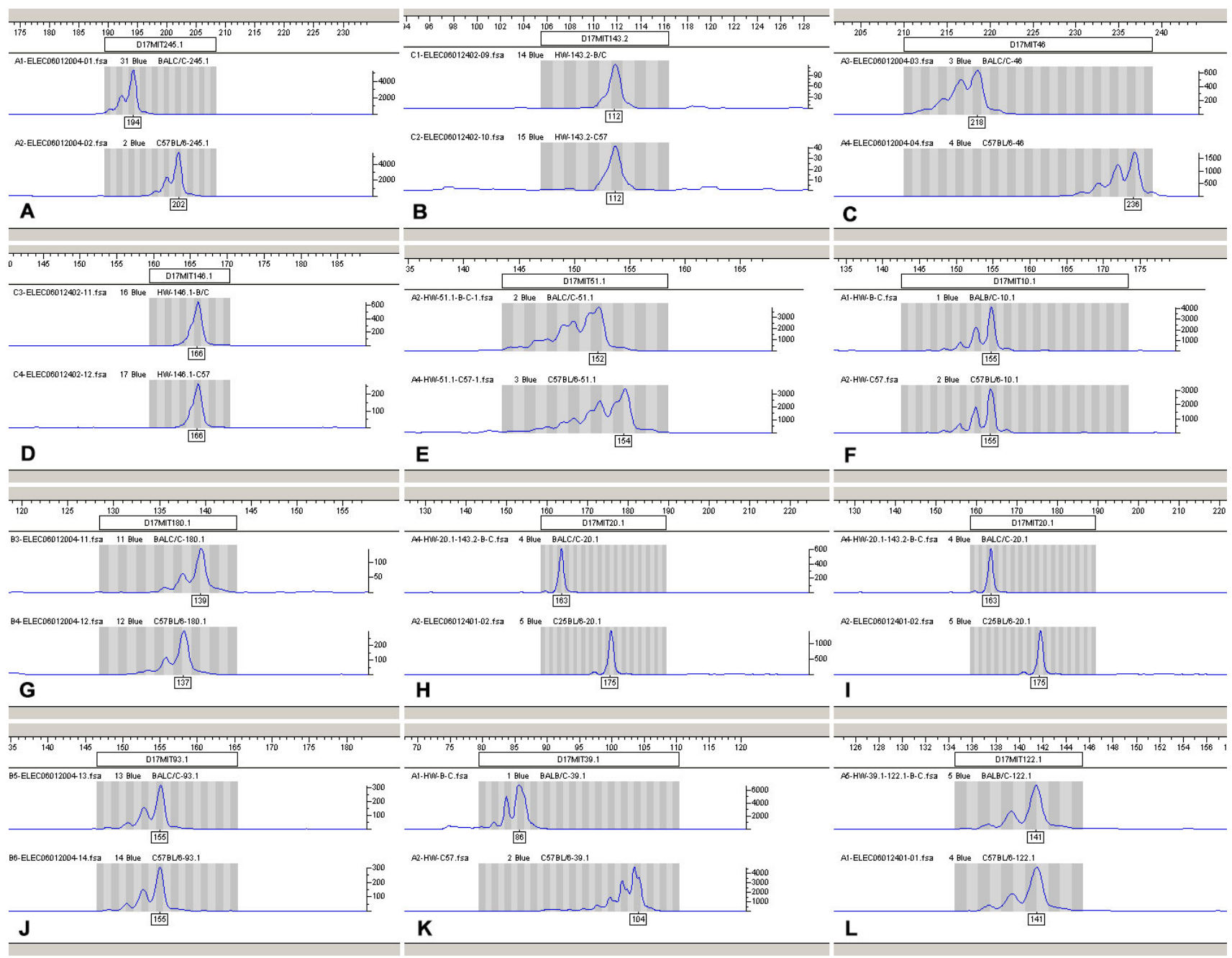

Figure 1: The microsatellite loci scanned using two mouse lines. A: D17MIT245.1; B: D17MIT143.2; C: D17MIT46; D: D17MIT46.1; E: D17MIT51.1; F: D17MIT10.1; G: D17MIT180.1; H: D17MIT20.1; I: D17MIT18; J: D17MIT93; K: D17MIT39.1; L: D17MIT122.1 


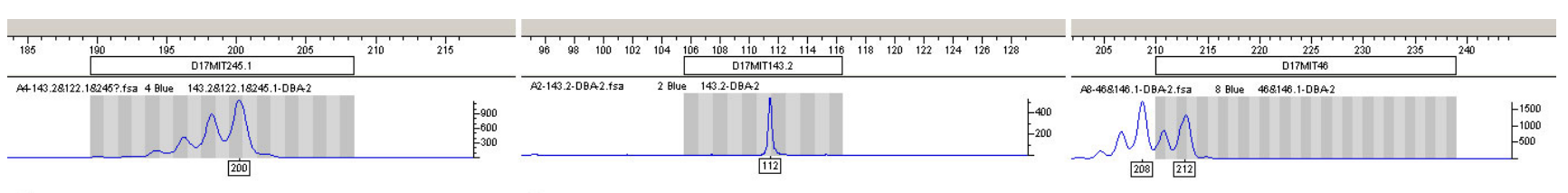

A

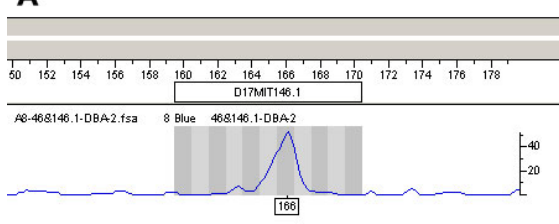

D

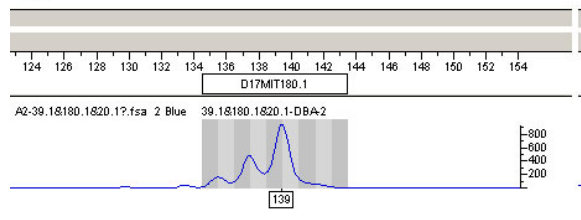

G

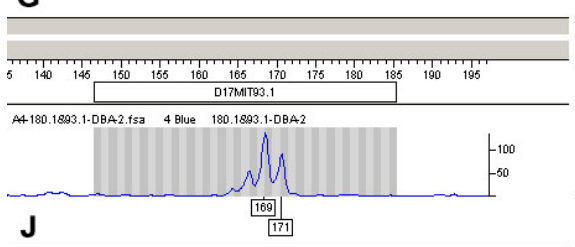

C

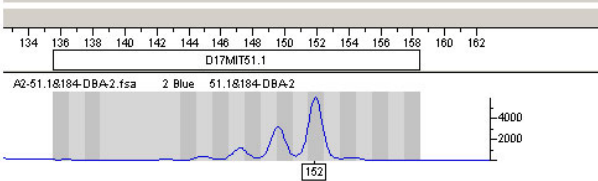

E

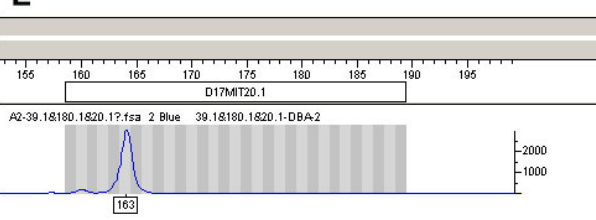

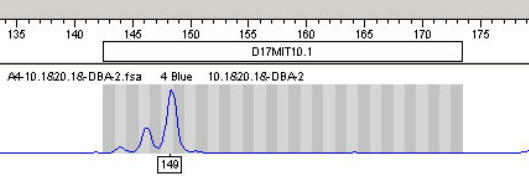

$\mathbf{F}$

H

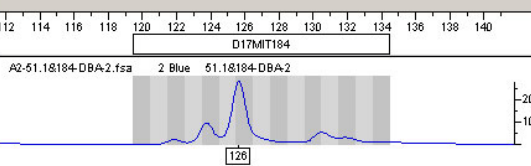

I
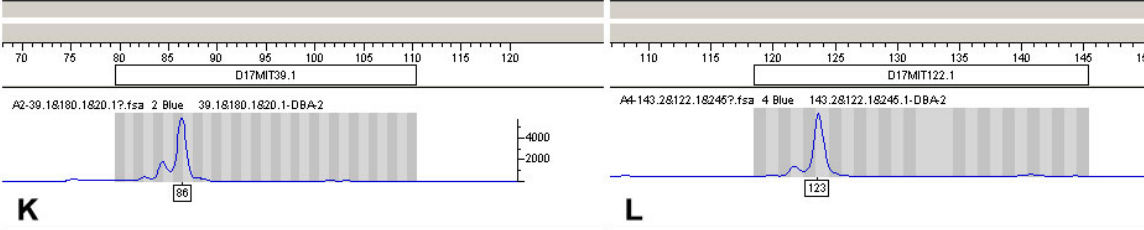

Figure 2: The microsatellite loci scan results of two DBA-2 mouse lines. A: D17MIT245.1; B: D17MIT143.2; C: D17MIT46; D: D17MIT46.1; E: D17MIT51.1; F: D17MIT10.1; G: D17MIT180.1; H: D17MIT20.1; I: D17MIT18; J: D17MIT93; K: D17MIT39.1; L: D17MIT122.1

As a viral disease seriously affecting human health with an increasing incidence in recent years, herpes simplex virus 1 (HSV-1) infection typically generates uncomfortable, watery blisters on the skin or mucous membranes of the mouth and lips, ${ }^{[9,10]}$ potentially leads to encephalitis with remarkable sequelae, or vesicle eruption on genital organs. ${ }^{[11]}$ More importantly, the eruption of these blisters and vesicles are frequently attributed to the long-term latent infection of HSV-1 in the nervous system. ${ }^{[12]}$ Although the human HSV infection rate is very high, it is difficult to fully attract people's attention, so it's difficult for us to associate HSV infection with genetic background. Therefore, most of the previous HSV infection studies focused on the acquired immune response after infection, showing that $\mathrm{T}$ cell-mediated immune response plays an important role in resisting HSV-1 infection, ${ }^{[13,14]}$ and immune suppressed or immune deficient individuals are vulnerable to opportunistic herpes virus infection. ${ }^{[15]}$ Furthermore, recent studies ${ }^{[16,17]}$ suggested that innate immune response plays a key role in limiting the spread of the virus. The development of innate immune germ line occurs earlier than acquired immune response system, ${ }^{[18]}$ and these two mechanisms function differently. This is undoubtedly an important point that genetic backgrounds play an important role in HSV infection. Meanwhile, the clinical symptoms of acute infection, as well as the long-term pathologic processes induced by recurrent latent infection, have been shown to closely correlate with the complex viral genome structures and the molecular mechanism of viral gene transcriptional regulation and replication. ${ }^{[19,20]}$

In fact, as early as 1975 , Lopez ${ }^{[1]}$ reported that there are significant differences in the genetic backgrounds of inbred mice that had significantly different reactions to the same or similar HSV infection, which undoubtedly suggested that genetic background might be an important factor for susceptibility to infection. This mechanism revealed by Lopez has also been confirmed by other studies. ${ }^{[2,3]}$ Also, there was a follow-up study on the relationship between the genetic background and susceptibility to HSV infection. Zawatzky et al. ${ }^{[21]}$ showed that compared with susceptible DBA/2 mice, the relatively tolerant C57BL/6 mice could produce more interferons in the immune response when it comes to HSV-1 infection. But Brenner et al. ${ }^{[22]}$ showed that there is no significant difference in the immune response to HSV infection among those two mouse lines. If the findings in mortality after infection phenotype, Simmons et al. ${ }^{[23]}$ reported that only one gene loci functions in this process, while Kastrukoff et al. ${ }^{[24]}$ reported that there were two loci separated in the role. We are inclined to believe that from the viewpoint of a gene associated with genetic background, it is undoubtedly that genetic background plays an important role in the phenotypic susceptibility to HSV infection. Since the genetic 
background is polygenic, and HSV has no apparent genetic background, the susceptibility of HSV infection itself is very likely regulated by more than one gene controlling quantitative traits.

By bioinformatics analysis, our results suggest that approximately 140 genes were found in the area of D17MIT51.1, D17MIT39.1 and the genomic region between D17MIT180.1 and D17MIT184, and functions of the majority of those genes are not fully revealed. There is a possibility that the above sites are related to the susceptibility to HSV infection, especially the growth-related genes which are highly suggestive of the importance of genetic background. Among these 140 genes, there were about 33 genes homologous to human genes. Their main functions include binding with other partners, regulating a variety of physiological processes, and the modulation of the phosphorylation process of various enzymes and coenzymes.

Based on our experimental results and bioinformatics analysis, the genetic background might play an important role in susceptibility to HSV infection, which is also consistent with most previous studies. It is worth noting that our finding is likely to be a quantitative trait locus, and may not be a particular system or population-specific mechanism. It is just a hint of this phenomenon in a particular system or population which has a relative higher or lower incidence in another race or ethnic groups. This is not consistent with some previous research.

In summary, the biological information and related data analysis suggest that these genes have important physiological and pathological functions. However, up to now, their associations with HSV susceptibility infection have not been reported, suggesting that they could be potential candidate genes that contributed to the different susceptibility to HSV infection.

Because HSV infection phenotypes have not been clearly defined yet, some issues are far from a consensus. For instance, whether the differences in response to HSV infection really exist and whether the genetic background plays a role in it. All these issues will undoubtedly limit the objectivity of this research. It is also necessary to validate the results in the present study by expanding the sample size, further investigating the role of the regulatory regions in regulating susceptibility to HSV infection. Furthermore, the functions of genes near these microsatellite loci, as well as their functions in regulating susceptibility, deserve further investigation.

\section{Financial support and sponsorship}

Nil.

\section{Conflicts of interest}

There are no conflicts of interest.

\section{Patient consent \\ There is no patient involved.}

\section{Ethics approval}

Ethics approval was obtained prior to the commencement of the study.

\section{REFERENCES}

1. Lopez C. Genetics of natural resistance to herpesvirus infections in mice. Nature 1975;258:152-3.

2. Kirchner H, Kochen M, Munk K, Hirt HM, Mergenhagen SE, Rosenstreich DL. Differences in susceptibility to herpes simplex virus infection of inbred strains of mice. IARC Sci Publ 1978;(24 Pt 2):783-8.

3. Lopez C. Resistance to herpes simplex virus - type 1 (HSV-1). Curr Top Microbiol Immunol 1981;92:15-24.

4. Cantin E, Tanamachi B, Openshaw H, Mann J, Clarke K. Gamma interferon (IFN-gamma) receptor null-mutant mice are more susceptible to herpes simplex virus type 1 infection than IFN-gamma ligand null-mutant mice. J Virol 1999;73:5196-200.

5. Umene K, Yamanaka F, Oohashi S, Koga C, Kameyama T. Detection of differences in genomic profiles between herpes simplex virus type 1 isolates sequentially separated from the saliva of the same individual. J Clin Virol 2007;39:266-70.

6. McLeod R, Buschman E, Arbuckle LD, Skamene E. Immunogenetics in the analysis of resistance to intracellular pathogens. Curr Opin Immunol 1995; 7:539-52.

7. Smith MW, Dean M, Carrington M, Winkler C, Huttley GA, Lomb DA, Goedert JJ, O'Brien TR, Jacobson LP, Kaslow R, Buchbinder S, Vittinghoff E, Vlahov D, Hoots K, Hilgartner MW, O'Brien SJ. Contrasting genetic influence of CCR2 and CCR5 variants on HIV-1 infection and disease progression. Hemophilia Growth and Development Study (HGDS), Multicenter AIDS Cohort Study (MACS), Multicenter Hemophilia Cohort Study (MHCS), San Francisco City Cohort (SFCC), ALIVE Study. Science 1997;277:959-65.

8. Lagrange PH, Abel L. The genetic susceptibility to leprosy in humans Acta Leprol 1996;10:11-27. (in French)

9. Xu F, Sternberg MR, Kottiri BJ, McQuillan GM, Lee FK, Nahmias AJ, Berman SM, Markowitz LE. Trends in herpes simplex virus type 1 and type 2 seroprevalence in the United States. JAMA 2006;296:964-73.

10. Fatahzadeh M, Schwartz RA. Human herpes simplex virus infections: epidemiology, pathogenesis, symptomatology, diagnosis, and management. J Am Acad Dermatol 2007;57:737-63; quiz 764-6.

11. Garland SM, Steben M. Genital herpes. Best Pract Res Clin Obstet Gynaecol 2014;28:1098-110.

12. Thompson RL, Sawtell NM. The herpes simplex virus type 1 latencyassociated transcript gene regulates the establishment of latency. $J$ Virol 1997; 71:5432-40.

13. Nash AA, Cambouropoulos P. The immune response to herpes simplex virus. Semin Virol 1993;4:181-6.

14. Rouse BT, Babiuk LA. Mechanisms of recovery from Herpesvirus infections - a review. Can J Comp Med 1978;42:414-27.

15. Posavad CM, Koelle DM, Shaughnessy MF, Corey L. Severe genital herpes infections in HIV-infected individuals with impaired herpes simplex virus-specific CD8+ cytotoxic T lymphocyte responses. Proc Natl Acad Sci U S A 1997;94:10289-94.

16. Biron $\mathrm{CA}$. Initial and innate responses to viral infections -- pattern setting in immunity or disease. Curr Opin Microbiol 1999;2:374-81.

17. Pien GC, Nguyen KB, Malmgaard L, Satoskar AR, Biron CA. A 
unique mechanism for innate cytokine promotion of $\mathrm{T}$ cell responses to viral infections. J Immunol 2002;169:5827-37.

18. Kimbrell DA, Beutler B. The evolution and genetics of innate immunity. Nat Rev Genet 2001;2:256-67.

19. Artusi S, Nadai M, Perrone R, Biasolo MA, Palu G, Flamand L, Calistri A, Richter SN. The Herpes Simplex Virus-1 genome contains multiple clusters of repeated G-quadruplex: Implications for the antiviral activity of a G-quadruplex ligand. Antiviral Res 2015;118:123-31.

20. Weir JP. Regulation of herpes simplex virus gene expression. Gene 2001;271:117-30.

21. Zawatzky R, Hilfenhaus J, Marcucci F, Kirchner H. Experimental infection of inbred mice with herpes simplex virus type 1. I.
Investigation of humoral and cellular immunity and of interferon induction. J Gen Virol 1981;53:31-8.

22. Brenner GJ, Cohen N, Moynihan JA. Similar immune response to nonlethal infection with herpes simplex virus-1 in sensitive (BALB/c) and resistant (C57BL/6) strains of mice. Cell Immunol 1994;157:510-24

23. Simmons A. H-2-linked genes influence the severity of herpes simplex virus infection of the peripheral nervous system. J Exp Med 1989;169:1503-7.

24. Kastrukoff LF, Lau AS, Puterman ML. Genetics of natural resistance to herpes simplex virus type 1 latent infection of the peripheral nervous system in mice. J Gen Virol 1986;67:613-21. 